\title{
Supplementary information for: Proton Relay Reaction in Green Fluorescent Protein (GFP): Isotopically Edited Polarization Resolved Ultrafast Vibrational Spectroscopy of GFP
}

\author{
Deborah Stoner-Ma ${ }^{\dagger}$, Edward H. Melief ${ }^{\dagger}$, Jerome Nappa, ${ }^{\ddagger}$ Michael Towrie ${ }^{\S}$ Kate L. \\ Ronayne, \\ Peter J. Tonge ${ }^{\dagger \perp_{*}}$ and Stephen R. Meech ${ }^{\ddagger *}$ \\ Contribution from the School of Chemical Sciences and Pharmacy, University of East Anglia, \\ Norwich NR4 7TJ, UK, Department of Chemistry and the Biochemistry and Structural Biology \\ Graduate Program, Stony Brook University, Stony Brook, New York 11794-3400, USA and \\ Rutherford Appleton Laboratory, Central Laser Facility, CCLRC, Didcot, Oxon, OX11 OQX UK
}

RECEIVED DATE (automatically inserted by publisher); E-mail: ptonge@notes.cc.sunysb.edu; s.meech@uea.ac.uk

In the following we present some of the structural information obtained from the DFT calculations (using the Gaussian 03 package $^{1}$ ). In figure S1 - S6 are shown the HBDI with the calculated atomic displacements (blue arrow) and transition dipole directions (yellow arrow) for, respectively, the $\mathrm{C}=\mathrm{O}$, $\mathrm{C}=\mathrm{C}$, Phenyl $1, \mathrm{C}=\mathrm{N}$, phenyl 2 and phenyl 3 modes. In each case the electronic transition dipole moment (calculated by Usman et al. $^{2}$ ) is also shown (green). In each figure the assignment is stated, along with the relative intensity scaled to the phenyl 1 mode and gas phase frequency calculated (which has been scaled by a constant factor 0.96 , the value recommended for $\mathrm{B} 3 \mathrm{LYP}^{3}$ ).

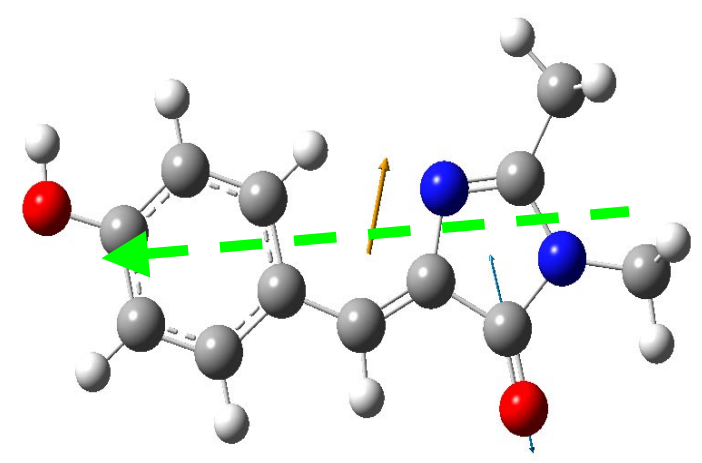

Figure $\mathrm{S} 1$. The $\mathrm{C}=\mathrm{O}$ mode $\left(0.61,1699 \mathrm{~cm}^{-1}\right)$

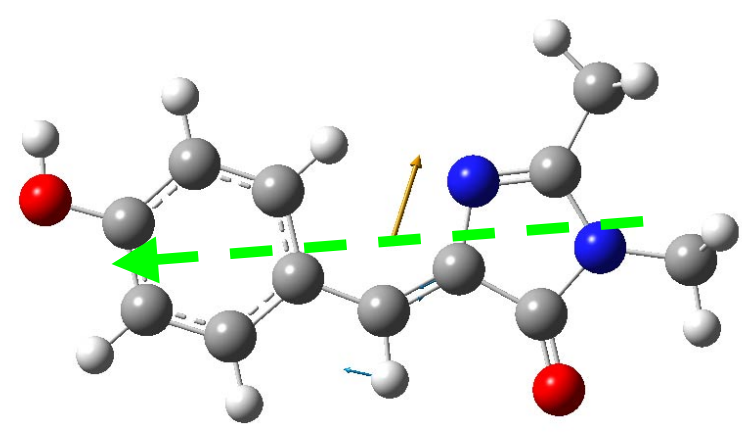

ure $\mathrm{S} 2$. The $\mathrm{C}=\mathrm{C}$ mode $\left(0.50,1626 \mathrm{~cm}^{-1}\right)$

Fig

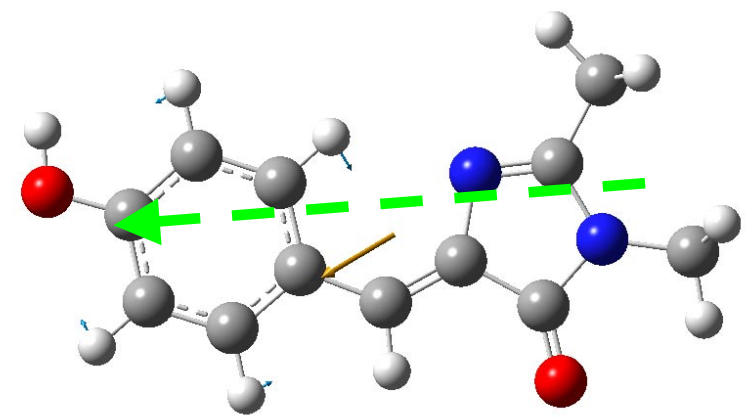

Figure S3. The Phenyl 1 mode $\left(1.0,1585 \mathrm{~cm}^{-1}\right)$ 


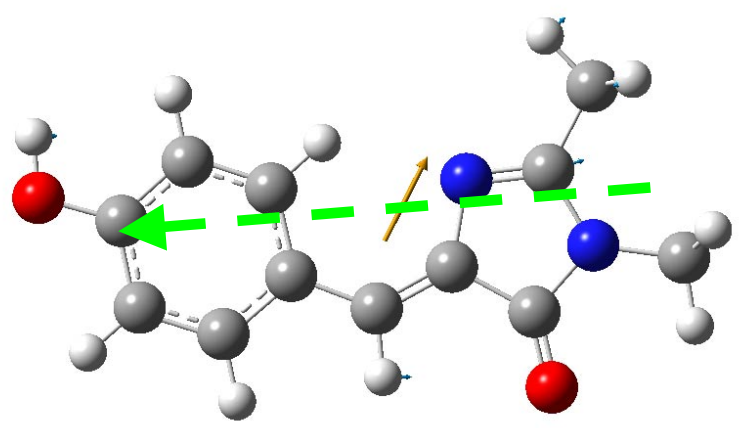

Figure $\mathrm{S} 4$. The $\mathrm{C}=\mathrm{N}$ mode $\left(0.02,1558 \mathrm{~cm}^{-1}\right)$

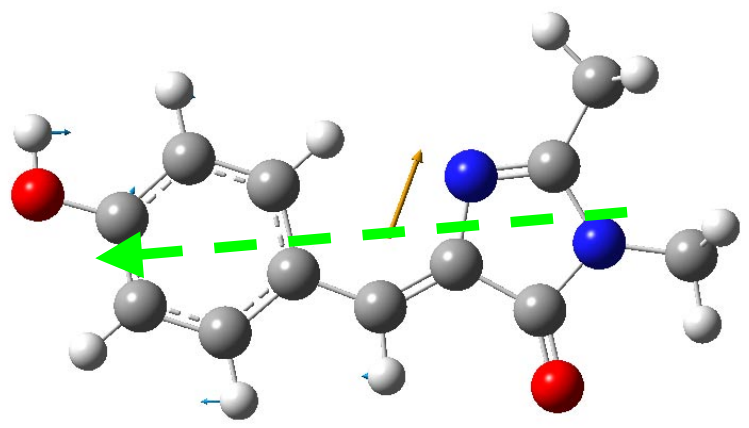

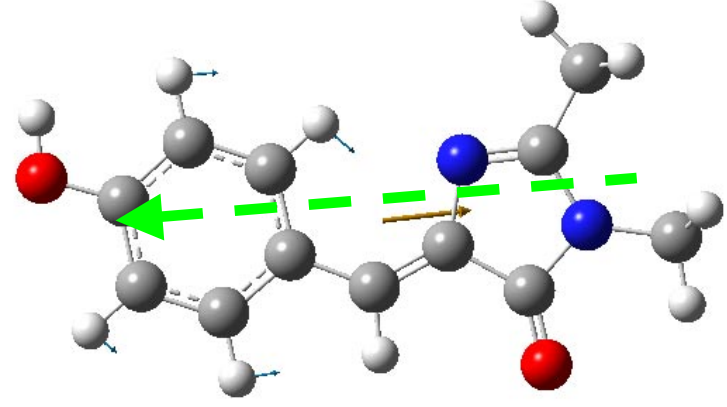

Figure S6 The Phenyl 3 mode $\left(0.20,1486 \mathrm{~cm}^{-1}\right)$

Figure S5. The Phenyl 2 mode $\left(0.08,1546 \mathrm{~cm}^{-1}\right)$

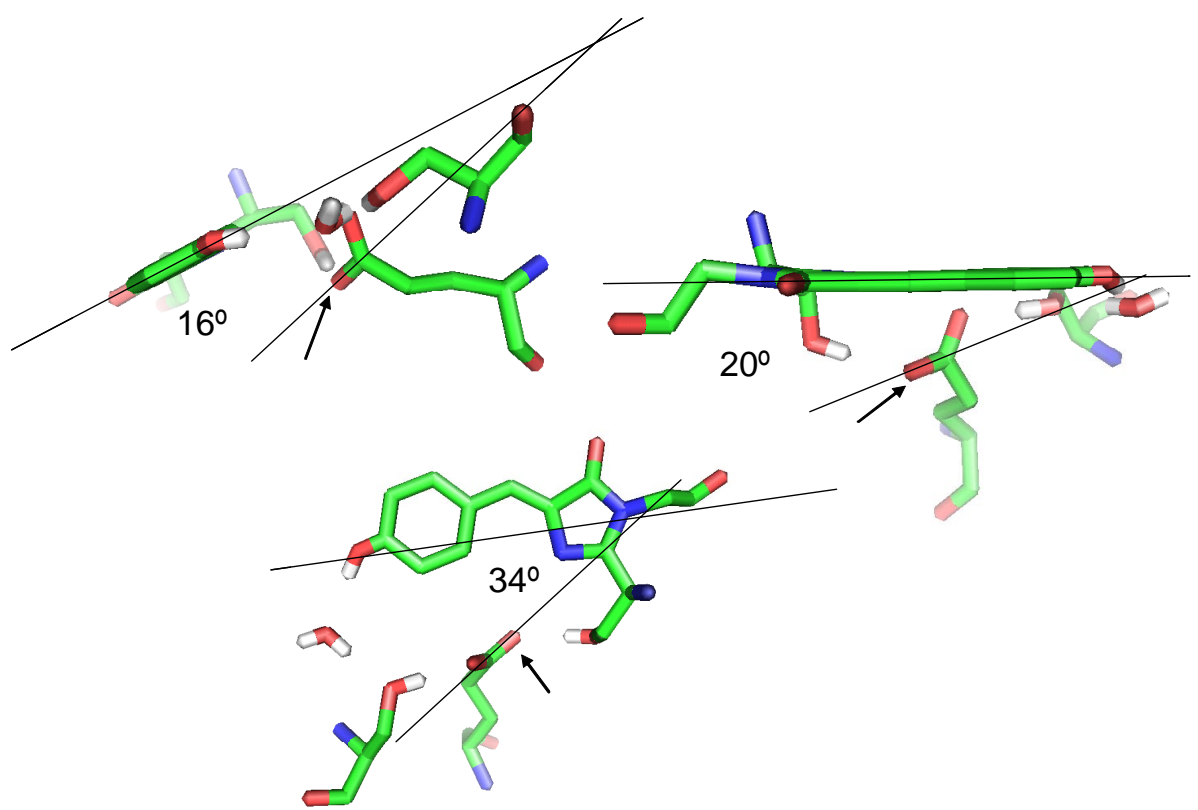

Figure S7 Showing the angle calculated between the carbonyl mode of the protonated E222 (indicated with a n arrow) residue and the transition moment of the chromophore.

\section{References}

1. Frisch, M. J.; Trucks, G. W.; Schlegel, H. B.; Scuseria, G. E.; Robb, M. A.; Cheeseman, J. R.; Zakrzewski, V. G.; Montgomery, J., J.A.; Stratmann, R. E.; Burant, J. C.; Dapprich, S.; Millam, J. M.; Daniels, A. D.; Kudin, K. N.; Strain, M. C.;
Farkas, O.; Tomasi, J.; Barone, V.; Cossi, M.; Cammi, R.; Mennucci, B.; Pomelli, C.; Adamo, C.; Clifford, S.; Ochterski, J.; Petersson, G. A.; Ayala, P. Y.; Cui, Q.; Morokuma, K.; Malick, D. K.; Rabuck, A. D.; Raghavachari, K.; Foresman, J. 
B.; Cioslowski, J.; Ortiz, J. V.; Baboul, A. G.; Stefanov, B. B.; Liu, G.; Liashenko, A.; Piskorz, P.; Komaromi, I.; Gomperts, R.; Martin, R. L.; Fox, D. J.; Keith, T.; Al-Laham, M. A.; Peng, C. Y.; Nanayakkara, A.; Gonzalez, C.; Challacombe, M.; Gill, P. M. W.; Johnson, B.; Chen, W.; Wong, M. W.; Andres, J. L.; Head-Gordon, M.; Replogle, E. S.; Pople, J. A., Gaussian 98 (Revision A.7). Gaussian, Inc., Pittsburgh PA: 1998.

2. Usman, A.; Mohammed, O. F.; Nibbering, E. T. J.; Dong, J.; Solntsev, K. M.; Tolbert, L. M., Excited-state structure determination of the green fluorescent protein chromophore. $J$. Am. Chem. Soc. 2005, 127, 11214-11215

3. Esposito, A. P.; Schellenberg, P.; Parson, W. W.; Reid, P. J., Vibrational spectroscopy and mode assignments for an analog of the green fluorescent protein chromophore. J. Mol. Struct. 2001, $569,25-41$. 